\title{
ERGO-PSYCHOPHYSIOLOGY DECREASING PHYSIOLOGICAL RESPONSES, INCREASING ALERTNESS, WORK ABILITY AND WORK ENGAGEMENT AT THE ACCOUNTING DEPARTMENT OF BALI HYATT HOTEL, DENPASAR
}

\author{
Handari-Adiputra, L. M. I. S., Pangkahila, A. J., Manuaba, I. B. A., Tirtayasa, K. \\ Physiology Department, School of Medicine, Udayana University \\ e-mail: luhmadeindah@yahoo.com
}

\begin{abstract}
Employee's performance can be determined from physiological responses, alertness, work ability and work engagement. The performance can be achieved when employees are able to adjust the capacity to the existing task demands, once is in accounting department. This department requires the ability to adjust the capacity of employees physiologically and psychologically with the tasks demands, one of the tasks was maintaining financial balance by using a computer. Employees work comfortably, safely, healthy thus increasing productivity. The working conditions need to be improved to prevent fatigue, complaints, discomfort, injury, stress, until disorder/disease that affects the company performance. It is to apply ergonomics interventions with emphasis on the psychological approach or Ergo-Psychophysiology.

Experimental studies have been carried out with treatment by subject design to the 17 employees at accounting department of Bali Hyatt Hotel, Denpasar. Sample performance observed when working in conventional condition (first period) and when working with treated Ergo-Psychophysiology (second period). Employee performance data between the two periods compared and analyzed by t-paired test at the significance level of 0.05 .

The data results showed that a decreased in the physiological response based on the decrease of fatigue was $22.18 \%$ and musculoskeletal complaints was $9.08 \%$. The alertness of employee increased based on increase of pace of work was $12.73 \%$, an increase of accuracy was $9.52 \%$ and increased of constancy was $21.62 \%$. An increased of work ability was $7.57 \%$ and an increased of work engagement was $16.73 \%(\mathrm{p}<0.05)$. There was no significance result for workload based on the working pulse $(\mathrm{p}>0.05)$. The results showed that the Ergo- Psychophysiological influenced employee performance based on physiological responses, alertness, work ability and work engagement, although the workload is not affected. This suggests that task demand of employment in the accounting department is more mental abilities than physical activity.

It was concluded that the Ergo-Psychophysiology decrease the physiological response based on the decrease in fatigue and musculoskeletal complaints. Ergo-Psychophysiology also increases alertness, work ability and work engagement. It is suggested to support on mental working condition in the accounting department.
\end{abstract}

Keywords: Ergo-Psychophysiology, Physiological Responses, Alertness, Work Ability, Work Engagement

\section{INTRODUCTION}

Work is performed by most of people because it is an obligation and also to live. By working person will get a reward or income in order to earn a living and meet their needs. For some people work is self- actualization. It means self potential can be realized and possessed higher expressed through working after other need such as physiological needs, safety, sense of belonging, and the other have been met. 
Balinese working population according to data from Statistics of Bali Province is 2,177,358 people from a population of 3,521,477 people, or by 61.83\% (BPS Prov. Bali, 2011a; BPS Prov. Bali, 2011b). A job in the tourism sector remains a favorite one. It can be seen from the BPS data in 2010 that showed that people who work in the trade, hotels and restaurants totaled 571,274 people.

Related to the work then there are factors that affect people can work optimally. These factors are work ability and work engagement. Work ability is the ability of a person to do the job, can be measured by the Work Ability Index (WAI) (Ilmarinen, 2007). Purnawati (2011) found that 12 bank employees had a mean work ability index 2.69 \pm 42.54 and are in the medium category. This indicates that the ability of employees still can be improved.

Work engagement is a positive mental state, fulfilling and related with work, can be measured by the Utrecht Work Engagement Scale (UWES) (Schaufeli and Bakker, 2003). From the preliminary study of seven employees at the financial administration in Bali College obtained the mean of work engagement was $3.387 \pm 0.543$ and classified in the category average. This showed that work engagement still be able to be improved.

Ergo-Psychophysiology selected to decrease workload, musculoskeletal complaints, fatigue, and increase alertness, work ability and work engagement at the accounting department of Bali Hyatt Hotel. These interventions also expected to improve employee performance and give beneficial for the hotel.

\section{METHODS}

This study was an experimental research with the treatment by subject design. The number of sample was 17 people. The comparability test using t-paired test with a significance level of $\alpha=0.05$.

\section{RESULTS}

1. Subject Characteristics
Table 1

Subject Characteristics $(\mathrm{n}=17)$

\begin{tabular}{cccc}
\hline Variable & Mean & SD & Variance \\
\hline Age (year) & 36.93 & 11.76 & $20-53$ \\
Weight $(\mathrm{kg})$ & 65.43 & 13.10 & $45-90$ \\
Height $(\mathrm{cm})$ & 167.36 & 5.33 & $160-175$ \\
IMT $\left(\mathrm{kg} / \mathrm{m}^{2}\right)$ & 23.19 & 3.44 & $18,6-29,4$ \\
$\quad$ Work & 12.23 & 9.74 & $0,25-27$ \\
$\begin{array}{c}\text { experience } \\
\text { (year) }\end{array}$ & & & \\
$\begin{array}{c}\text { Sistole (mmHg) } \\
\text { Diastole } \\
\text { (mmHg) }\end{array}$ & 114.47 & 16.63 & $90-147$ \\
\hline
\end{tabular}

2. Environmental Conditions

Table 2

Environmental Conditions

\begin{tabular}{lccc}
\hline \multicolumn{1}{c}{ Variable } & Mean & SD & Variance \\
\hline $\begin{array}{l}\text { Temperature } \\
\left({ }^{0} \mathrm{C}\right)\end{array}$ & 28.68 & 0.08 & $28.60-28.80$ \\
$\begin{array}{l}\text { Relative } \\
\text { Humidity (\%) }\end{array}$ & 59.52 & 2.21 & $57.20-62.20$ \\
$\begin{array}{l}\text { Light intensity } \\
\text { (lux) }\end{array}$ & 284.19 & 97.84 & $141.60-458.40$ \\
\hline
\end{tabular}


3. Subject Anthropometric

Table 3

Anthropometric Data $(\mathrm{n}=17)$

\begin{tabular}{lcc}
\hline \multicolumn{1}{c}{ Anthropometric } & $\begin{array}{c}\text { Percentile- } \\
5(\mathrm{~cm})\end{array}$ & $\begin{array}{c}\text { Percentile-95 } \\
(\mathrm{cm})\end{array}$ \\
\hline Seat height & 80.60 & 90.60 \\
Eye height & 67.60 & 80.60 \\
Shoulder height & 51.00 & 61.00 \\
Elbow height & 19.60 & 27.40 \\
Waist height & 16.20 & 27.00 \\
Thighs thick & 10.00 & 17.80 \\
Buttock-knee & 49.80 & 58.80 \\
distance & & \\
Buttock-poplitea & 41.20 & 48.20 \\
distance & & \\
Knee height & 51.00 & 60.00 \\
Poplitea height & 41.60 & 50.40 \\
Shoulder width & 35.40 & 48.80 \\
Waist width & 22.40 & 34.80 \\
Hips width & 27.00 & 41.20 \\
Chest thick & 11.20 & 24.80 \\
Belly thick & 13.60 & 30.00 \\
Long sleeve top & 30.00 & 36.80 \\
Forearm length & 30.40 & 38.40 \\
Elbow to finger & 40.00 & 49.40 \\
distance & & \\
Elbow to thumb & 33.60 & 40.80 \\
distance & & \\
Elbow to elbow & 41.00 & 55.60 \\
width & & \\
The high range & 106.00 & 128.60 \\
\hline
\end{tabular}

4. Workload

Table 4

Result of Working Pulse t-paired test

\begin{tabular}{|c|c|c|c|c|c|}
\hline Periode & $\mathrm{n}$ & $\begin{array}{l}\text { Worki } \\
\text { ng } \\
\text { Pulse } \\
\text { (bpm) }\end{array}$ & SD & $\mathrm{t}$ & $\mathrm{p}^{*}$ \\
\hline
\end{tabular}

\begin{tabular}{lccccc}
$1^{\text {st }}$ & & & & & \\
Periode & 17 & 69.18 & 6.83 & & \\
$2^{\text {nd }}$ & 17 & 69.00 & 7.54 & & \\
Periode & & & & & \\
\hline * comparable $\mathrm{p}>0.05$ & & & & \\
\hline
\end{tabular}

5. Fatigue

Table 5

Result of fatigue t-paired test after Work

\begin{tabular}{lccccc}
\hline Periode & $\mathrm{n}$ & $\begin{array}{c}\text { Fatigue } \\
\text { Score } \\
\text { Mean }\end{array}$ & SD & $\mathrm{t}$ & $\mathrm{p}^{*}$ \\
\hline $\begin{array}{l}1^{\text {st }} \\
\text { Periode }\end{array}$ & 17 & 41.65 & 5.29 & & \\
$2^{\text {nd }}$ & 17 & 32.41 & 2.18 & & \\
\begin{tabular}{l} 
Periode \\
\multicolumn{4}{l}{$*$ comparable $\mathrm{p}>0.05$}
\end{tabular} & & & & \\
\hline
\end{tabular}

6. Musculoskeletal Complaints

\begin{tabular}{lccccc}
\hline Periode & $\mathrm{n}$ & $\begin{array}{c}\text { Musculoske } \\
\text { letal } \\
\text { Complaints } \\
\text { Score Mean }\end{array}$ & SD & $\mathrm{t}$ & $\mathrm{p}$ \\
\hline $1^{\text {st }}$ & 17 & 35.00 & 4.21 & & \\
Periode & 17 & 31.82 & 2.72 & 4.70 & 0.001 \\
$2^{\text {nd }}$ & 17 & & & \\
Periode & & Table 6 & &
\end{tabular}

Results of musculoskeletal complaints tpaired test after Work

*comparable $\mathrm{p}>0.05$

7. Alertness

Table 7

Result of alertness t-paired test after Work

Variable $\quad \mathrm{n} \quad$ Periode $\quad \mathrm{t} \quad \mathrm{p}$




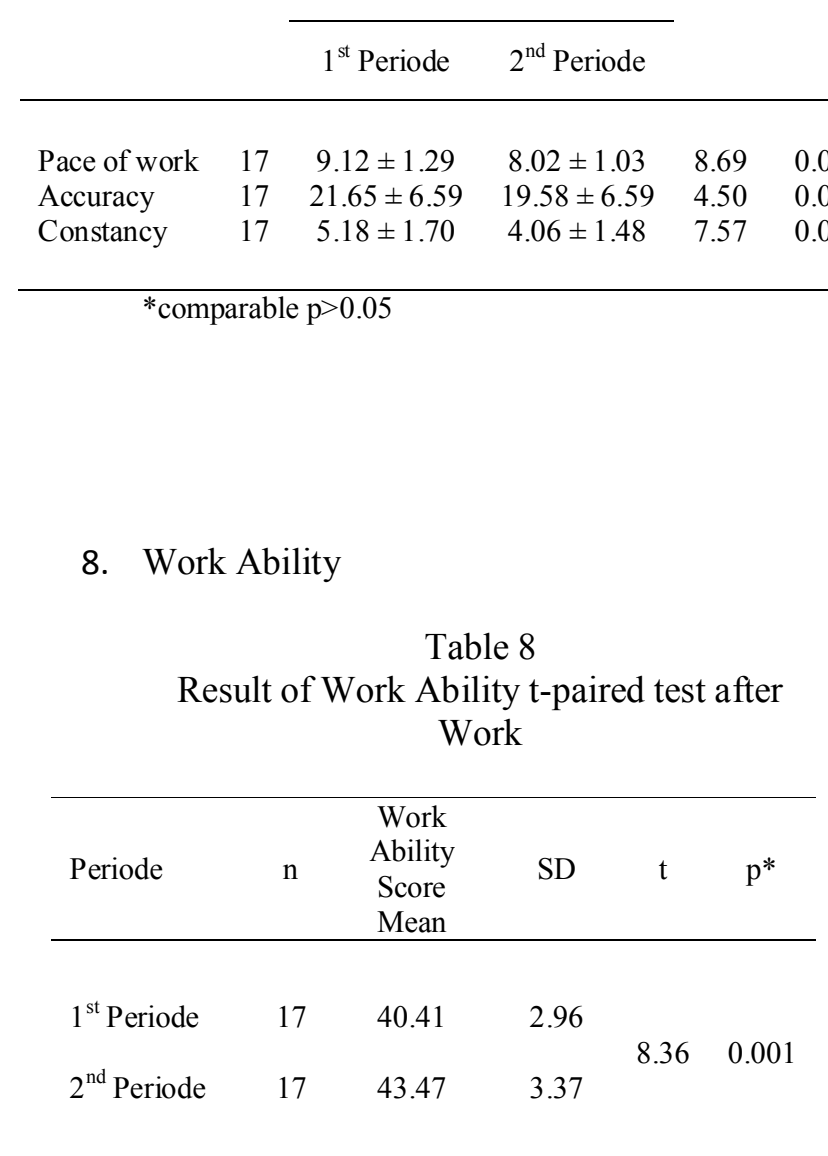

* comparable $\mathrm{p}>0.05$

9. Work Engagement

Table 9

Result of Work Engagement t-paired test after Work

\begin{tabular}{llllll}
\hline Periode & $\mathrm{n}$ & $\begin{array}{c}\text { Work } \\
\text { engageme } \\
\text { nt Score } \\
\text { Mean }\end{array}$ & SD & $\mathrm{t}$ & $\mathrm{p}^{*}$ \\
\hline
\end{tabular}

$\begin{array}{llllll}1^{\text {st }} \text { Periode } & 17 & 57.99 & 13.20 & & \\ 2^{\text {nd }} & 17 & 67.69 & 11.37 & & \\ \text { Periode II } & 17 & & & & \end{array}$

*comparable $\mathrm{p}>0.05$

\section{DISCUSSION}

The study found that the variation in the age of employees between 20-53 years with a mean $36.93 \pm$ 0.0011 .76 years. Weight varies between $45-90 \mathrm{~kg}$ with a 0.00 mean of $65.43 \pm 113.10 \mathrm{~kg}$. Height varies between $0.001160-175 \mathrm{~cm}$ with a mean of $167.36 \pm 5.33 \mathrm{~cm}$. Body mass index varied from 18.60 to $29.40 \mathrm{~kg} / \mathrm{m}^{2}$ with a mean of $23.19 \pm 3.44 \mathrm{~kg} / \mathrm{m}^{2}$. A mean of systolic and diastolic blood pressure were $114.47+16.63 \mathrm{mmHg}$ and $77.82 \pm 12.86 \mathrm{mmHg}$.

The mean air temperature at the accounting department of Bali Hyatt Hotel X was $28.68 \pm 0.08$ ${ }^{0} \mathrm{C}$. The mean relative humidity was $59.52 \pm 2.21 \%$, and there is no air movement can be measured by the anemometer. While the measurement of light intensity obtained mean $284.19 \pm 97.84$ lux.

Table 4 showed that the mean of working pulse first period was $69.18 \pm 6.83 \mathrm{bpm}$ and in second period was $69.00 \pm 7.54 \mathrm{bpm}$. Analysis of significance with t-paired test showed that the value of $t=0.392$ and $p=0.703$. This means that the the mean of working pulse in both periods did not differ $(p>0.05)$. A job in the accounting department can be categorized as a job with a very light workload. In doing their job, the employee do not need a lot of physical activity, but rather to work with the demands of mental activity.

Table 5 showed that the mean score of fatigue in the first period was $41.65 \pm 5.29$ and second period was $32.41 \pm 2.18$. Analysis of significance with t-paired test showed that the value of $t=9.02$ and $p=0.001$. This means that in the two groups in both periods, the mean fatigue significantly different $(p<0.05)$. An increase of fatigue in the first period because of several factors, such as job demands/workload and energy expenditure. Someone needs energy to maintain body functions, and when the physical work increased energy needs. Reduction in fatigue was $22.19 \%$. Adiatmika (2007) found that improvements in working conditions with total ergonomics approach can significantly reduce fatigue from a score of 37.77 to 35.37 or $6.79 \%$ at painting metal crafters in Kediri Tabanan. 
Table 6 showed that the mean score of musculoskeletal complaints in the first period was $35.00 \pm 4.21$ and in second period was $31.82 \pm 2.72$. Analysis of significance with t-paired test showed that the value of $t=4.70$ and $p=0.001$. This means that the mean musculoskeletal complaints in both periods were significantly different $(p<0.05)$. Musculoskeletal complaints arising in the first period due to the load on the muscles, especially in the area of the back, hips, shoulders, and neck because employees work sitting in a chair, using a computer with the static position for long time.

According Manuaba (1998), the force posture at work and last long cause the load on the musculoskeletal system and the negative effects on health. Purnawati (2012) reported that there was a decrease of $10.5 \%$ musculoskeletal complaints after being given Ergo-JSI on national private bank employee in Denpasar Bali. In the application of Ergo-JSI, employees working posture ergonomically improved such as the eye height is to adjust the height of the computer monitor, runway utilization leg and foot space, and the use of the backrest.

Meanwhile, Indrawati (2013) reported that there is a decrease of $71.99 \%$ musculoskeletal complaints after stretching training and active rest on employees BRM in Sanglah Hospital. The mean of musculoskeletal complaints after working on the PI was 16.89 and $77.36+45.56+11.92$ on PII. There has been a significant decline.

Table 7 showed that the alertness between first period to second period significantly different $(\mathrm{p}$ $<0.05$ ). Indrawati (2013) found that an increase in pace of work by $80.06 \%, 61.89 \%$ increase in accuracy and constancy $40.08 \%$ on employee medical records Sanglah Hospital after being given training stretching and active rest. Increase in the mean of pace of work on PI was 26.03 to 15.00 on PII. The mean accuracy on PI was 18.01 to 13.5 on PII. The mean constancy on PI was 7.22 to 6.23 on PII.

Darmadi (2009) found that the pace of work in the control group and the intervention group showed a mean difference in the rate of 0.83 or 10.75 $\%$. The level of accuracy increased 2.89 or $35.94 \%$. Constancy rate increased 0.80 or $20.78 \%$. Wijayanti (2009) reported that there is a significant decrease in pace of work, accuracy and constancy after improve work posture by using tables and chairs when working practices on Carving junior high school students. Decrease in pace of work can be seen from the decrease in the mean was $10.11 \pm 0.42$ on P0 to $7.30 \pm 0.29$ on P1. The mean decrease in accuracy was $12.81 \pm 1.36$ on $\mathrm{P} 0$ to $3.6 \pm 0.71$ on P1. The mean decrease of constancy was $7.74 \pm 2.42$ on $\mathrm{P} 0$ to $3.63 \pm 0.46$ on $\mathrm{P} 1$.

Table 8 showed that the mean score on the work ability of the first period was $40.41 \pm 2.96$ and $43.47 \pm 3.37$ on second period. Analysis of significance with t-paired test showed that the value of $t=8.36$ and $p=0.001$. This means that the mean of work ability in both periods were significantly different $(p<0.05)$. Important factors that can reduce working capacity is the lack of vigorous leisure -time physical activity, poor musculoskeletal capacity, older age, obesity, and high physical and psychosocial work demands (Van de Berg et al., 2009). Vedovato et al. (2009) reported that the decrease in WAI related with psychosocial factors, such as stress and musculoskeletal diseases that occur in the study of teachers in Germany were reported by Freude, Seibt, Pech and Ullsperger in 2005. Mazloumi et al. (2012) reported that the job demand is one of the risk factors to reduce work ability. Purnawati (2012) showed that there was an increase of $4.72 \%$ WAI scores on national private bank employee in Denpasar, Bali after being given Ergo-JSI. This increase occurred because the ErgoJSI change working conditions as well as changes in knowledge, attitudes and behavior of employees on matters relating to workplace stress and how to anticipate them.

Table 9 showed that the mean work engagement score in first period was $57.99 \pm 13.20$ and $67.69 \pm 11.37$ on second period. Analysis of significance with t-paired test showed that the value 
of $\mathrm{t}=9.15$ and $\mathrm{p}=0.001$. This means that the mean score in both periods significantly different $(\mathrm{p}<$ 0.05 ). The decline work engagement after work is consistent with what is stated by Sonnentag et al. (2010; within Bakker et al., 2012) that there is fluctuation of work engagement. Most of the previous studies that measured using the design work engagement between individuals and can not explain why even an employee who engaged high might have an off day and sometimes showed poor performance or below average. Researchers then tried to start measuring the change in the daily work engagement. It turns out people are not always engaged all day at work. There are days when employees feel more vigorous, absorbed, and dedicated than other days.

In the JD - R models mentioned that there are two main things that affect work engagement, namely job demands and job resources. Job demands was the initiator of the process of health improvement and job resources is the initiator of the process of motivation. Most of the studies showed that job resources are more important in determining a person's work engagement. However, in this study it can be proven otherwise that job demands can also define work engagement with ErgoPsychophysiology intervention.

Ergo-Psychophysiology intervention can improve work engagement by reducing the task demand, create ergonomics work environment, making it more comfortable and safe at work.

\section{CONCLUSIONS}

1. Ergo-Psychophysiology not decreased physiological responses based on physical workload at accounting department Bali Hyatt Hotel, Denpasar.

2. Ergo-Psychophysiology decreased physiological responses based on employee fatigue at accounting department Bali Hyatt Hotel, Denpasar.

3. Ergo-Psychophysiology decreased physiological responses based on muskuloskeletal complaints at accounting department Bali Hyatt Hotel, Denpasar.

4. Ergo-Psychophysiology increased alertness at accounting department Bali Hyatt Hotel, Denpasar.

5. Ergo-Psychophysiology increased work ability at accounting department Bali Hyatt Hotel, Denpasar.

6. Ergo-Psychophysiology increased work enaggement at accounting department Bali Hyatt Hotel, Denpasar.

\section{FUTURE WORK}

1. Ergo-psychophysiology need to be applied to similar types of work as it gives a good impact on employee performance.

2. Ergo-psychophysiology may be an option in improving employee performance.

\section{REFERENCES}

Adiatmika, I P. G. 2007. Perbaikan Kondisi Kerja dengan Pendekatan Ergonomi Total Menurunkan Keluhan Muskuloskeletal dan Kelelahan Serta Meningkatkan Produktivitas dan Penghasilan Perajin Pengecatan Logam di Kediri Tabanan. (Disertasi). Denpasar: Universitas Udayana.

Bakker, A. B., Demerouti, E., Xanthopoulou, D. 2012. How Do Engaged Employees Stay Engaged? Ciencia \& Trabajo. Year 14. Special Issues. p.15-21. Bakker, A. B., Demerouti, E., Xanthopoulou, D. 2012. How Do Engaged Employees Stay Engaged? Ciencia \& Trabajo. Year 14. Special Issues. p.15-21.

BPS Prov. Bali. 2011a. Bali dalam Angka 2011: Kondisi Ketenagakerjaan Menurut Jenis Kelamin di Propinsi Bali Tahun 2010. [cited 2012 June 01]. Available from :URL:http://bali.bps.go.id/tabel_detail.php? ed $=605001 \&$ od $=5 \&$ id $=5$ 
BPS Prov. Bali. 2011b. Bali dalam Angka 2011: Jumlah Penduduk Warga Negara Indonesia dan Warga Negara Asing Menurut Jenis Kelamin dan Kabupaten/Kota di Bali Akhir Tahun 2010. [cited 2012 June 01]. Available from:URL:http://bali.bps.go.id/tabel_detail.php $?$ ed $=604002 \&$ od $=4 \&$ id $=4$

BPS Prov. Bali. 2011c. Bali dalam Angka 2011: Penduduk 15 Tahun ke Atas yang Bekerja Seminggu yang Lalu Menurut Lapangan Usaha dan Jenis Kelamin di Provinsi Bali Tahun 2010. [cited 2012 June 01]. Available from:URL:http://bali.bps.go.id/tabel_detail.php $?$ ed $=605001 \&$ od $=2 \&$ id $=5$

Darmadi, I G. W. 2009. Aplikasi Ergonomi pada Penggunaan Liquid Crystal Display Projektor Menurunkan Kelelahan Mata dan Meningkatkan Konsentrasi Belajar Mahasiswa Jurusan Kesehatan Lingklungan Poltekkes Denpasar. (thesis). Denpasar: Universitas Udayana.

Demerouti, E. dan Bakker, A. B. 2011. The Job Demands-Resources Model: Challenges for Future Research. SA Journal of Industrial Psychology. 37(2), Art.\#974, 9 pages. doi:10.4102/sajip.v37i2.974.

Ilmarinen, J. 2007. The Work Ability Index (WAI). Occupational Medicine, 57:160.

Indrawati, E. P. 2013. Pelatihan Peregangan dan Istirahat Aktif Menurunkan Keluhan Muskuloskeletal, Kelelahan Mata dan Meningkatkan Konsentrasi Kerja Karyawan Rekam Medis Rumah Sakit Sanglah Denpasar. (thesis). Denpasar: Universitas Udayana.

Manuaba, I. B. A. 1998. Bunga Rampai Ergonomi. Vol I. Denpasar: Program Studi ErgonomiFisiologi Kerja Universitas Udayana.
Mazloumi, A., Rostamabadi, A., Saraji, G. N., dan Foroushani, A. R. 2012. Work Ability Index (WAI) and Its Association with Psychosocial Factors in One of the Petrochemical Industries in Iran. $J$ Occup Health. Vol.54, No.2, p.112118.

Purnawati, S. 2011. Work Ability Index, Indeks Stres dan Job Satisfaction pada Karyazanh Bank "X" Bali. Prosiding Seminar Nasional Perhimpunan Ergonomi Indonesia ke-11. Jakarta.

Purnawati, S. 2012. Aplikasi Program Manajemen Stres Kerja Berbasis Ergonomi (Ergo-JSI) Menurunkan Stres Kerja Karyawan Bank Swasta Nasional "X" di Denpasar Bali. (disertasi). Denpasar: Universitas Udayana.

Schaufeli, W. B. dan Bakker, A. B. 2003. UWES Preliminary Manual. Utrecth: Utrecht University.

Van den Berg, T. I. J., Elders, L. A. M., dan Burdorf, A. 2009. The Effects of Work-Related and Individual Factors on Work Ability: A Systematic Review. (in Kumashiro, M. (Editor). Promotion of Work Ability Towards Productive Aging. CRC Press. Taylor \& Francis Group: London.

Vedovato, T. G. dan Monteiro, I. 2009. Factors Associated to the Work Ability among Brazilian Teachers. (in Kumashiro, M. (Editor). Promotion of Work Ability Towards Productive Aging. CRC Press. Taylor \& Francis Group: London.

Wijayanti, N. P. L. 2009. Perbaikan Sikap Kerja dengan Penggunaan Meja dan Kursi Kerja Mengurangi Keluhan Muskuloskeletal dan Meningkatkan Konsentrasi Praktek mengukir Siswa SMP Seni Ukir Tangeb. (thesis). Denpasar: Universitas Udayana 